\title{
Mycoplasma Hyosynoviae in Joints with Arthritis in Abattoir Baconers
}

\author{
By N.F. Friis, K. K. Hansen, A. L. Schirmer and S. Aabo \\ National Veterinary Laboratory, Copenhagen and Mesinge, Denmark.
}

\begin{abstract}
Friis, N.F., K.K. Hansen, A.L. Schirmer and S. Aabo: Mycoplasma hyosynoviae in joints with arthritis in abattoir baconers. Acta vet. scand. 1992, 33, 205-210. The occurrence of Mycoplasma hyosynoviae in synovial fluid of baconers with chronic arthritis was studied at an abattoir. Cultural examination of synovial fluid samples from diseased tarsal joints of 50 animals from 42 herds yielded $M$. hyosynoviae in 10 cases from 8 herds. Streptococci were found in 6 cases from 6 other herds. M. hyosynoviae antigen was found in 1 of 47 of the samples, and antibody to the mycoplasma was found in 14 of 40 of the samples by ELISA test. The presence of $M$. hyosynoviae in a joint was usually accompanied by the corresponding antibody. In joints with streptococcal infection antibody to $M$. hyosynoviae could not be found.
\end{abstract}

swine.

\section{Introduction}

Chronic arthritis is a fairly common finding at meat inspection in baconers at abattoirs. The larger joints of the legs, mainly stifle and elbow (Cross \& Edwards 1981) are affected with various non-suppurative lesions (Bond 1976, Johnston et al. 1987, Meijer et al. 1975, Ross et al. 1977, Turner 1982) which apparently reflects the later phases of an infection. The lesions are usually characterized by an increased amount of a viscous and brownish synovial fluid sometimes accompanied by a hypertrophic thickening of the joint capsule and erosion of the cartilage.

Several microorganisms have been isolated and the bacterium, Erysipelothrix rhusiopathiae appears to be the most frequent finding and is often ascribed the etiologic role for the lesions (Bond 1976, Johnston et al. 1987, Meijer et al. 1975, Turner 1982). Other bacteria may be found as well. Mycoplasma hyo- synoviae is also known to cause arthritis that may persist to the time of slaughter (Ross \& Duncan 1970, Ross et al. 1971, 1977). $M$. hyosynoviae is a well-known arthritogenic pathogen among swine in this country (unpublished) and it is often isolated from inflamed joints in herds with enzootically occurring arthritis among animals in the age groups from 30 to $100 \mathrm{~kg}$. Also other microorganisms may be recovered from inflamed joints of younger pigs; thus E. rhusiopathiae and various streptococci are often found (Jorsal, personal communication).

The aim of the present work was to investigate the occurrence of $M$. hyosynoviae in chronic arthritis, and to compare cultivation to demonstration of antigen and antibody by an immunodiagnostic method, the enzymelinked immunosorbent assay (ELISA). Cultivation for bacteria was performed for comparison. 


\section{Materials and Methods}

Arthritic samples

A sample of synovial fluid from inflamed tarsal joints was aspirated aseptically from 50 slaughterhouse pigs with a body weight of $100 \mathrm{~kg}$ and representing 42 herds. Diseased joints were revealed from enlargement and brownish discoloration of regional lymph nodes in combination with distension of joint capsules. Most samples of synovial fluid appeared turbid and yellowish-brownish discolored.

The samples were sent by ordinary mail to the Laboratory $(24 \mathrm{~h})$ from November through February and were immediately processed for microbiological examination. The samples were kept at $-25^{\circ} \mathrm{C}$ for later immunodiagnostic examination.

\section{Isolation of mycoplasmas and bacteria}

Two different media (Friis et al. 1991) were used for cultivation of mycoplasmas: A Hayflick's type of medium enriched with arginine and mucin was used for M. hyosynoviae, while for other species a medium originally intended for Mycoplasma hyopneumoniae was used. Isolated mycoplasmas were identified by the disc growth inhibition test (DGI) (Friis 1974) with antiserum for reference strain M60, serologically indistinguisable from the type strain S16 of $M$. hyosynoviae.

Examination for bacteria was performed by inoculation of the synovial fluid onto $5 \%$ calf-blood agar (Columbia blood agar base, Oxoid) in 3 different dilutions and by aerobic incubation at $37^{\circ} \mathrm{C}$. The plates were read after 24 and $48 \mathrm{~h}$ incubation. The bacteriological diagnosis was based on ordinary cultural and biochemical characteristics. Lancefield's serological grouping of streptococci was performed as a capillary precipitation test.

\section{Immunodiagnostic examinations}

Antisera. Rabbit antiserum to $M$. hyosynoviae reference strain M60, Mycoplasma hyorhinis type strain BTS-7 and Mycoplasma bovirhinis type strain PG43 was produced (Friis \& Jensen 1984) with organisms harvested from cultures in rabbit broth (Friis 1977). For cultivation of $M$. hyosynoviae the broth was enriched with arginine and mucin (Friis et al. 1991). Crude IgG was produced by precipitation with $\left(\mathrm{NH}_{4}\right)_{2} \mathrm{SO}_{4}$ followed by purification on a DEAE-Sephadex A-50 column as described by Harboe \& Ingild (1983). Forty $\mathrm{mg}$ crude $\mathrm{IgG}$ dissolved in $10 \mathrm{ml}$ carbonate buffer $\mathrm{pH} 9.6$ was biotinylated using $54 \mathrm{mg}$ biotin-amidocaproate $\mathrm{N}$-hydroxysuccinimide ester (Sigma B-2643) in $500 \mu$ l dimethylsulphoxide (DMSO, Sigma D5879) mainly as described by Guesdon et al. (1979).

Antigens. Antigens of the 3 mycoplasmas were harvested by surface washing with PBS of 3 days old cultures on solid pig-serum-free Hayflick's medium enriched (above) with arginine/mucin and $15 \%$ horse serum. The cell suspensions were washed $4 \mathrm{x}$ in PBS and the final pellet dissolved in $5 \mathrm{ml}$ distilled water and freeze-thawed 5 cycles. After centrifugation at 5,000 x g (average) for $20 \mathrm{~min}$, PBS was added to the supernatant to $25 \mathrm{ml}$ which was stored at $-25^{\circ} \mathrm{C}$ as antigen for ELISA.

ELISA for detection of antigen. Wells of Nunc-Immuno-Plates, maxisorp (Nunc, Roskilde, Denmark) were coated with $0.2 \mathrm{ml}$ IgG (1:1,000 of original serum volume in 0.1 $\mathrm{M}$ carbonate buffer $\mathrm{pH} 9.6$ ) to $M$. hyosynoviae or $M$. hyorhinis and incubated overnight at $+4^{\circ} \mathrm{C}$. The plate was tapped dry and washed $4 \mathrm{x}$ in a hypertonic diluent (PBS-T) consisting of $\mathrm{NaCl} 0.5 \mathrm{M}, \mathrm{Na}_{2} \mathrm{HPO}_{4} 0.01 \mathrm{M}$, 
$\mathrm{KH}_{2} \mathrm{PO}_{4} 0.003 \mathrm{M}, 0.05 \%$ Tween 20 (Merck) and $\mathrm{pH}$ adjusted to 7.4 with $\mathrm{K}_{2} \mathrm{HPO}_{4} 1.0 \mathrm{M}$. Synovial fluid was added in dilutions $1 / 1,1 / 3$, $1 / 10,1 / 30,1 / 100$ in PBS-T in a volume of 0.1 $\mathrm{ml}$ (all later volumes being $0.1 \mathrm{ml}$ ) incubated for $1 \mathrm{~h}$ at $37^{\circ} \mathrm{C}$ and washed as above, and biotinylated IgG for $M$. hyosynoviae added (diluted 1:10,000 in PBS-T) and incubated for $1 \mathrm{~h}$ at $37^{\circ} \mathrm{C}$. After washing, horseradish peroxydase-conjugated avidin (Dako, Herlev, Denmark) diluted 1:7,500 in gelatine buffer $(2.5 \mathrm{~g}$ gelatine in $500 \mathrm{ml}$ PBS-T, $10 \mathrm{~min}$ in $37^{\circ} \mathrm{C}$ water bath) was added and left for $1 \mathrm{~h}$ at room temperature and washed with PBS-T and also once in citric acid buffer $(0.035 \mathrm{M}$ citric acid and $0.066 \mathrm{M} \mathrm{Na}_{2} \mathrm{HPO}_{4}, \mathrm{pH} 5.0$ ). Enzyme substrate (8 mg 1.2-orthophenyl-diamine dihydrochloride, $12 \mathrm{ml}$ citric acid buffer, $5 \mu \mathrm{H} \mathrm{H}_{2} \mathrm{O}_{2}$ ) was added and color development stopped with $0.5 \mathrm{M} \mathrm{H}_{2} \mathrm{SO}_{4}$ after $10 \mathrm{~min}$. Spectrophotometrical absorption was read at $490 \mathrm{~nm}$ using $650 \mathrm{~nm}$ as reference. Values for $M$. hyosynoviae were regarded as positive, if they were at least $100 \%$ above both control figures as obtained from the wells coated with IgG to $M$. hyorhinis and from synoviafree wells and values $50-100 \%$ above as dubious. A positive reaction was obtained for broth cultures of $M$. hyosynoviae M60 in dilution $1 / 300$, corresponding to approx. $10^{5}$ organisms per $\mathrm{ml}$.

ELISA for detection of antibody. Wells were coated with $0.2 \mathrm{ml}$ antigen of $M$. hyosynoviae and M. bovirhinis (approx. 300 $\mathrm{ng} /$ well) diluted in carbonate buffer (above) kept overnight at $+4^{\circ} \mathrm{C}$ and washed. Synovial fluid, $0.1 \mathrm{ml}$ of dilutions $1 / 10,1 / 20,1 / 40$, $1 / 80,1 / 160$ was added and incubated $1 \mathrm{~h}$ at $37^{\circ} \mathrm{C} ; 1 / 40,1 / 80$ and $1 / 160$ made by diluting $1 / 20$ in PBS-T with 5\% SPF pig serum. Washing and reacting with peroxydase-conjugated, rabbit anti-pig immunoglobulin, diluted 1:1,000, for $1 \mathrm{~h}$ at room temperature. Addition of enzyme substrate and reading of the plates as above. Figures of at least $100 \%$ above control values as obtained from the wells with IgG to $M$. bovirhinis and from synovia-free wells, were noted as positive, and $50-100 \%$ above as dubious. The rabbit hyperimmune antiserum was found positive for M. hyosynoviae in dilution 1:40,000.

\section{Results}

M. hyosynoviae was isolated from 10 samples from 8 farms (Table 1) by cultivation of 50

Table 1. Isolation of mycoplasmas and bacteria from arthritic tarsal synovial samples of 50 abattoir baconers and examination of the samples for Mycoplasma hyosynoviae antigen and antibody by ELISA.

\begin{tabular}{|c|c|c|c|c|}
\hline & Synovial samples examined & & esults & \\
\hline \multirow[t]{2}{*}{ Cultivation } & \multirow[t]{2}{*}{50} & \multicolumn{2}{|c|}{$\begin{array}{l}10 \text { M. hyosynoviae isolates } \\
6 \text { Streptococci* isolates }\end{array}$} & \\
\hline & & Negative & Dubious & Positive \\
\hline \multicolumn{5}{|l|}{ ELISA $* *$} \\
\hline Antigen & 47 & 45 & 1 & 1 \\
\hline Antibody & 40 & 17 & 9 & $14^{* * *}$ \\
\hline
\end{tabular}


Table 2. Antigen and antibody of Mycoplasma hyosynoviae demonstrated by ELISA in 16 arthritic tarsal synovial samples from which mycoplasmas or streptococci were isolated.

\begin{tabular}{cccccccc}
\hline $\begin{array}{c}\text { Sample } \\
\text { number }\end{array}$ & M. hyosynoviae* & Antigen** & Antibody** & $\begin{array}{c}\text { Sample } \\
\text { number }\end{array}$ & Streptococci & Antigen & Antibody \\
\hline 48 & 1 & 0 & $\mathrm{~d}$ & & & & \\
10 & 1 & nd & nd & 13 & Gr L & 0 & 0 \\
4 & 2 & 0 & d & 14 & Gr L & 0 & 0 \\
24 & 2 & 0 & 20 & 17 & Gr L & 0 & nd \\
26 & 2 & 0 & 0 & 27 & Gr C & 0 & 0 \\
49 & 2 & 0 & 40 & 31 & Gr C & 0 & 0 \\
46 & 2 & 0 & nd & 41 & Gr C & 0 & nd \\
50 & 2 & 3 & nd & & & & \\
39 & 3 & 0 & 160 & & & & \\
9 & 4 & 0 & nd & & & & \\
\hline
\end{tabular}

* $\quad$ Figures indicate endpoint for growth as reciprocal of $\log 10$ dilution.

** Positive reaction indicated as reciprocal of dilution.

$\mathrm{d}=$ Dubious reaction for antibody to $\mathrm{M}$. hyosynoviae by ELISA.

nd $=$ Not done.

$0=$ Negative.

arthritic joint fluids of pigs collected at a slaughterhouse. Moreover, 6 isolates of bacteria were obtained from pigs from 6 other farms; all of them identified as streptococci, 3 Group C and 3 Group L.

By ELISA, antigen of $M$. hyosynoviae was demonstrated in 1 of 47 examined samples (Table 1). This sample was also positive by culture (Table 2). Another sample reacted dubious at the antigen examination and it was found positive in the antibody test. Antibody to $M$. hyosynoviae was found in 14 of 40 examined samples. A further 9 samples were recorded as dubious.

$M$. hyosynoviae was isolated in 6 cases among the 40 samples examined in the antibody test (Table 2). Three of these were serologically positive, 2 were dubious and 1 was negative. Streptococci were isolated in 4 cases, all without any reaction for antibody to $M$. hyosynoviae in the synovial fluid.

\section{Discussion}

M. hyosynoviae was cultivated from $20 \%$ of examined arthritic lesions of pigs from an abattoir, generally in low numbers. Antigen was found by ELISA in $2 \%$ and antibody in $35 \%$. As $17(43 \%)$ of 40 samples examined by all 3 procedures reacted positive for $M$. hyosynoviae in at least 1 test with a further 7 (17\%) reacting dubious, it appears reasonable to suggest that $M$. hyosynoviae has been involved in the etiology of the examined cases of chronic arthritis. Further, the results are in agreement with the chronic nature of the lesions as antibody is by far the most frequent of the 3 parameters. Among the 16 negative samples streptococci were isolated in 4 cases probably representing other etiologies of the lesions.

The very low number ( 1 positive, 1 dubious) of samples reacting for antigen of $M$. hyosynoviae may be surprising. However, the low number of organisms obtained by cultivation 
$\left(\leq 10^{4}\right)$ are all below the detection limit $\left(10^{5}\right)$ for demonstration by ELISA in broth cultures (see Materials and Methods). Further, the chronic nature of the lesions may imply that many epitopes are already occupied by specific antibodies resulting in false negative tests.

The values for antibody in the joint fluids, as estimated by the ELISA test, are low as compared to a value of 40,000 for the rabbit antiserum. The immunoglobulins may at least partially have been produced locally in the joint capsule, as excessive accumulations of lymphoid and plasma cells have earlier been found in experimental studies with $M$. hyosynoviae (Ross \& Duncan 1970). In experimental work with Erysipelothrix rhusiopathiae, Timoney \& Yarkoni (1976) tentatively suggest a capability for local production of antibody.

In some studies on the etiology of the arthritis in abattoir baconers, authors have mainly focussed upon E. rhusiopathiae (Bond 1976, Johnston et al. 1987, Meijer et al. 1975, Turner 1982) regarding it as the prime cause as it is often found in about half of examined lesions, contrary to few isolations of M. hyosynoviae (Johnston et al. 1987, Ross et al. 1977). During the present investigation an almost opposite situation was revealed as E. rhusiopathiae was actually not isolated although it is a fairly common cause of arthritis in younger pigs. However, according to N.C. Nielsen (personal communication) a reasonable explanation for this failure may be the fact that tarsal joints of animals earlier infected with $E$. rhusiopathiae usually show anchylosis and periarticular exostosis without increased synovium in $100 \mathrm{~kg}$ baconers, having therefore escaped the synovial sampling. Even if present such synovium does usually not produce $E$. rhusiopathiae anymore when cultured.
It therefore appears that different microorganisms may be etiologically involved in the chronic arthritis found among baconers.

\section{References}

Bond MP: Polyarthritis of pigs in western Australia: The role of Erysipelothrix rhusiopathiae. Aust. vet. J.1976, 52, 462-467.

Cross GM, Edwards MJ: The detection of arthritis in pigs in an abattoir and its public health significance. Aust. vet. J. 1981, 57, 153-158.

Friis NF: Mycoplasmas in pigs with special regard to the respiratory tract. Thesis, DSR Forlag. Copenhagen 1974.

Friis NF: Mycoplasma suipneumoniae and Mycoplasma flocculare in the growth precipitation test. Acta vet.scand. 1977, 18, 168-175.

Friis NF, Jensen PT: Serological comparison of type strains of porcine, bovine and ovine mycoplasmas with atypical colony morphology. Acta vet. scand. 1984, 25, 29-35.

Friis NF, Ahrens $P$, Larsen $H$ : Mycoplasma hyosynoviae isolation from the upper porcine respiratory tract. Acta vet. scand. 1991, 32, 425-429.

Guesdon J-L, Ternynck T, Avrameas $S$ : The use of avidin-biotin interaction in immunoenzymatic techniques. J. Histochem. Cytochem. 1979, 27, 1131-113.

Harboe NMG, Ingild A: Immunization, isolation of immunoglobulins and antibody titre determination. Scand. J. Immunol. 1983, 17, suppl. 10, 345-351.

Johnston KM, Doige CE, Osborne AD: An evaluation of nonsuppurative joint disease in slaughter pigs. Can. vet. J. 1987, 28, 174-180.

Meijer P, Goudswaard J, Goedegebuure SA, Budhai $S$ : Immunological, bacteriological and morbidanatomical features of arthrosis/arthritis of the stifle joint in swine. Tijdschr. Diergeneesk. 1975, 100, 1109-1117.

Ross RF, Duncan JR: Mycoplasma hyosynoviae arthritis of swine. J. Amer. vet. med. Ass. 1970, 157, 1515-1518.

Ross RF, Switzer WP, Duncan JR: Experimental production of Mycoplasma hyosynoviae arthritis in swine. Amer. J. vet. Res. 1971, 32, 1743-1749.

Ross $R F$, Weiss $R$, Kirchhoff $H$ : Nachweis von $M$. hyorhinis und $M$. hyosynoviae in arthritischen Gelenken von Schweinen. (Demonstration of M. hyorhinnis and M. hyosynoviae in arthritic 
joints of pigs). Zbl. Vet. Med. B 1977, 24, 741745.

Timoney JF, Yarkoni $U$ : Immunoglobulins IgG and IgM in synovial fluids of swine with Erysipelothrix polyarthritis. Vet. Microbiol. 1976, 1, 467-474.

Turner GVS: A microbiological study of polyarthritis in slaughterpigs. J. South African vet.

Ass. 1982, 53, 95-101.

\section{Sammendrag}

Mycoplasma hyosynoviae's atiologiske betydning ved artritis hos slagterisvin.

Betydningen af $M$. hyosynoviae for udviklingen af de kroniske ledbetændelser, som optræder hos baconsvin på et slagteri er blevet undersøgt. Ved dyrkning fra 50 haseled af dyr fra 42 besætninger fandtes $M$. hyosynoviae i 10 tilfælde fra 8 besætninger, medens streptokokker fandtes i yderligere 6 tilfælde fra 6 andre besætninger. Med ELISA proceduren fandtes antigen af $M$. hyosynoviae i 1 af 47 af prøverne og korresponderende antistof i 14 af 40 af prøverne. Tilstedeværelse af $M$. hyosynoviae i led var sædvanligvis ledsaget af antistof mod mykoplasmen; dette var ikke tilfældet i prøver med fund af bakterier. Det må anses for sandsynligt, at $M$. hyosynoviae er årsag til mange af disse kroniske ledbetændelser, medens bakterier formodentlig er ansvarlige for de $\emptyset$ vrige.

(Received February 11, 1992; accepted May 22, 1992).

Reprints may be requested from: N. F. Friis, National Veterinary Laboratory, Bülowsvej 27, DK-1790 Copenhagen V, Denmark. 